\title{
Korelasi Media Audio Visual Dengan Hasil Belajar Kelas IV Tema 3 Subtema 1 Pembelajaran 1 Di SD Negeri Belahantengah Mojokerto
}

\author{
${ }^{1}$ Riska Nur Aulia, ${ }^{2}$ Ida Sulistyawati, ${ }^{3}$ Susi Hermin Rusminati \\ PGSD Universitas PGRI Adi Buana Surabaya \\ riskanuraulia@gmail.com¹ , keke.idaadi81@gmail.com², susiherminr@unipasby.ac.id ${ }^{3}$
}

\begin{abstract}
Abstrak
Media yang menggabungkan dua unsur sekaligus yaitu media audio dimana menggunakan unsur suara yang melibatkan indera pendegaran dan media visul yang menggunakan unsur gambar yang melibatkan indera penglihatan disebut media audio visual.

Tujuan dari penelitian ini adalah untuk mengetahui apakah ada hubungan antara media audio visul dengan hasil belajar kelas IV tema 3 subtema 1 pembelajaran 1 . Metode dan jenis penelitian yang digunakan dalam penelitian ini adalah penelitian korelasi kuantitatif. Populasi dalam penelitian ini adalah seluruh peserta didik kelas IV SD Negeri Belahantengah Mojokerto yang berjumlah 31 peserta didik dengan teknik sampel jenuh.

Teknik pengumpulan data menggunakan angket dan tes. Adapun teknik analisis data yang digunakan yakni uji normalitas, uji linieritas, dan uji korelasi. Hasil uji korelasi menghasilkan adanya korelasi media audio visual dengan hasil belajar kelas IV tema 3 subtema 1 pembelajaran 1 . Hal ini berdasarkan uji korelasi dengan menggunakan bantuan spss diketahui $r_{\text {hitung }}>r_{\text {tabel }}$ yaitu $0,831>0,355$. Dengan taraf signifikasi (Sig) $\alpha=0,05$. Sehingga hipotesis Ha yang menyatakan terdapat korelasi antara media audio visual dengan hasil belajar kelas IV tema 3 subtema 1 pembelajaran 1 dapat diterima.
\end{abstract}

Kata Kunci: media audio visual, hasil belajar, tematik 


\section{PENDAHULUAN}

Suatu proses yang dilalui seseorang dan memiliki nilai mendidik disebut belajar. Nilai yang bersifat mendidik dapat diperoleh melalui berbagai cara, mulai dari aktifitas fisik hingga aktifitas pikir yang dilakukan dengan lingkungan sekitarnya. Terjadinya perubahan tingkah laku menjadi lebih baik pada diri seseorang merupakan bukti bahwa telah melakukan dan mengalami proses belajar.

Aktivitas dalam proses pembelajaran merupakan kondisi yang sengaja diciptakan oleh guru sebagai pendidik agar dapat mengantarkan peserta didiknya ke tujuan pembelajaran. Tugas guru disini harus mampu membuat suasana proses belajar di dalam kelas menjadi menyenangkan sehingga disukai seluruh peserta didik. Kondisi proses belajar mengajar yang disukai peserta didik ini dapat berpengaruh terhadap tercapainya tujuan pembelajaran.

Hal sederhana yang dapat dilakukan untuk menjadikan suasana pembelajaran menjadi disukai peserta didik adalah kegiatan pembelajaran yang dilaksanakan dengan menggunakan bantuan media pembelajaran. Dengan begitu maka materi pembelajaran yang sulit dan rumit akan jauh lebih mudah dipahami oleh peserta didik ketika proses belajar berlangsung.

Seiring berkembangnya teknologi, media pembelajaran juga ikut berkembang menjadi lebih modern. Salahsatu contohnya berupa media pembelajaran audio visual yang merupakan kombinasi 2 (dua) media pembelajaran, terdiri dari media audio (pendengaran) dan media audio (penglihatan)

Suatu proses pembelajaran dengan mengaplikasikan media audio visual memiliki kelebihan yaitu diantaranya materi yang diberikan dapat lebih cepat dipahami oleh peserta didik. Dikarenakan materi yang diperoleh dapat dirasakan dan dilihat secara langsung oleh indera penglihatan dan pendegaran peserta didik, bukan sekedar berangan-angan atau berimajinasi.

Semangat belajar yang tumbuh pada diri peserta didik yang disebabkan oleh penggunaan media audio visual akan berdampak pada semakin fokus dan aktifnya peserta didik pada kegiatan pembelajaran yang berlangsung. Kondisi yang demikian apabila berlangsung secara terus menerus, maka peserta didika akan 
memperoleh hasil dari proses belajarnya secara memuaskan atau sesuai dengan harapannya.

Setelah selesainya suatu kegiatan pembelajaran agar memahami apakah sudah terpenuhi tujuan pembelajaran tersebut. Maka dibutuhkan kegiatan evaluasi yang dikelompokkan menjadi 3 (tiga) yaitu bidang intelektual (kognitif), bidang sikap (afektif) serta bidang keterampilan (psikomotor).

Berdasarkan penjelasana tersebut diatas, peneliti ingin menjawab permasalahan "Apakah terdapat korelasi antara media audio visual dengan hasil belajar kelas IV tema 3 subtema 1 pembelalajaran 1 di SD Negeri Belahantengah Mojokerto?'. Peneliti berharap agar penelitian ini dapat memberikan konstribusi baik berupa referensi maupun pengetahuan tentang korelasi media audio visual dengan hasil belajar.

Berdasarkan permasalahan tersebut, penelitian ini juga didukung dan diperjelas dengan beberapa dasar teori. Menurut (Arsyad, 2013) "Peralatan yang digunakan untuk menyampaikan pesan belajar disebut media. ${ }^{1}$ " Djamarah dan Zain (2014:124) menyatakan "Media pembelajaran yang memiliki 2 (dua) unsur sekaligus secara bersamaan, yaitu unsur audio/ atau suara dan unsur visual/ atau gambar disebut media audio visual."

Media audio visual yang diaplikasikan dalam proses pembelajaran memiliki beberapa kelebihan dan kekurangan. Adapun menurut Suryani, dkk (2018:53) kelebihannya yaitu sebagai berikut: (1) pembelajaran yang diperoleh peserta lebih efektif, karena baik dengan gaya bahasa audio maupun visual dalam terlayani dengan baik; (2) pengalaman belajar jauh lebih jelas atau nyata; (3) peserta didik lebih gampang memahami materi, dikarenakan materi yang diperoleh peserta didik secara langsung bukan sekedar berangan-angan; (4) peserta didik lebih tertarik dan lebih senang jika pembelajaran memakai atau dengan mengaplikasikan media audio visual. Sedangkan kekurangannya yaitu sebagai berikut: (1) waktu pembuatan media yang relatif lama; (2) dalam pembuatannya dibutuhkan kreatifitas dan ketelitian; (3) mahalnya biaya pembuatan media; (4)

\footnotetext{
${ }^{1}$ Arsyad, A. Media Pembelajaran. (Jakarta: Pustaka Belajar.2013),hal,14
} 
apabila peralatan yang dibutuhkan tidak ada, maka akan mengalami kesulitan dalam pembuatan medianya. ${ }^{2}$

Berdasarkan paparan tersebut, maka penulis berpendapat bahwa media audio visual merupakan media audio dimana dengan unsur suara yang mengandalkan indera pendegaran dan media visual dimana menggunakan unsur gambar yang mengandalkan indera penglihatan yang digabungkan secara bersamaan sekaligus.

Belajar sebagaimana yang dijelaskan oleh (Fanani \& Kusmaharti, 2018) mendefinisikan "peserta didik melakukan berbagai aktivitas fisik dan pikir untuk mencapai tujuan tertentu. Sehingga terjadi suatu perubahan sikap yang bertambah baik disebut dengan belajar."3 Sedangkan (Dimyanti \& Mudjiono, 2013) mendefinisikan "hasil yang didapatkan dari interaksi dalam proses kegiatan belajar mengajar disebut dengan hasil belajar". ${ }^{4}$ Serta (Purwanto, 2013) juga mendefinisikan "Hasil belajar merupakan suatu proses belajar mengajar yang diikuti peserta didik sehingga dapat terjadi tercapainya keberhasilan tujuan pembelajaran". 5

Menurut (Leksono \& Yustitia, 2016) dalam suatu proses belajar, terdapat aspek utama yang memodifikasi hasil belajar. Pertama: fakrot dari dalam diri individu (internal), terdiri dari aspek fisiologis, aspek otak, dan aspek psikologis (ilmu jiwa). Kedua: faktor eksternal (dari luar diri individu), terdiri dari lingkungan sosial dan lingkungan non-sosial. Ketiga: faktor kedekatan pembelajaran. $^{6}$

Berdasarkan uraian yang sudah dijabarkan, maka penulis berpendapat bahwa hasil belajar merupakan suatu proses belajar mengajar yang dilakukan

\footnotetext{
${ }^{2}$ Suryani, N., \& Dkk. Media Pembelajaran Inovatif dan Pengembangannya. (Bandung: Rosda Karya.2018),hal.43

${ }^{3}$ Fanani, A., \& Kusmaharti, D. Pengembangan Perangkat Pembelajaran Sekolah Dasar. (Surabaya: Adi Buana University Press.2018),hal,51

${ }^{4}$ Dimyanti \& Mudjiono. Belajar\&Pembelajaran. In belajar\&pembelajaran.

${ }^{5}$ Purwanto. (2013). Evaluasi Hasil Belajar. (Yogyakarta: Pustaka Belajar,2013),hal,18

${ }^{6}$ Leksono, I. P., \& Yustitia, V. (2016). Belajar dan Pembelajaran. (Surabaya: Adi Buana University Press.2016),hal,72
} 
peserta didik melalui berbagai interaksi aktivitas fisik dan pikir sehingga dapat terjadi keberhasilan dan tercapainnya tujuan pembelajaran.

Sistem pendidikan di sekolah dasar sekarang menggunakan sistem kurikulum pendidikan tahun 2013 yaitu dimana sistem pendidikan dengan menerapkan pembelajaran bertema terpadu. Pembelajaran tema sendiri berarti sistem dimana beberapa mata pelajaran dirancang menjadi bertema dimana dengan menghubungkan beberapa KD (Kompetensi Dasar), Indikator, dan SI (Standar Isi) secara sengaja. ${ }^{7}$

\section{METODE PENELITIAN}

Jenis dan metode penelitian yang digunakan dalam penelitian ini yaitu penelitian kuantitatif korelasi. Faenkel dan Wallen (dalam Siswanto dan Suyanto, 2018:17) menyatakan bahwa "Penelitian korelasi adalah sebuah eksperimen atau riset dilakukan dengan tujuan melihat adanya ikatan antara 2 (dua) variabel atau lebih tanpa adanya pemalsuan variabel”.

Seluruh peserta didik kelas IV SD Negeri Belahantengah Mojokerto merupakan populasi yang digunakan dalam penelitian ini. Teknik sampling jenuh adalah teknik yang digunakan, maka seluruh peserta didik kelas IV SD Negeri Belahantengah Mojokerto dengan total 31 peserta didik merupakan sampel dalam penelitian ini.

Penelitian ini memerlukan 2 (dua) bantuan teknik pengumpulan data yakni angket dan tes. Lembar angket dan lembar tes merupakan teknik pengumpulan data yang dipakai. Pada instrumen penelitian lembar angket menggunakan jenis angket tertutup dengan skala likert. Dimana dalam lembar angket tersebut, responden hanya menuliskan tanda centang atau checklist $(\sqrt{ })$ pada jawaban yang dianggapnya benar. Sedangkan pada lembar tes, soal yang diberikan berjumlah 20 soal yaitu 15 soal multiple choice dan 5 soal isian singkat.

Analisis data dikerjakan dengan menggunakan. Pertama yaitu uji prasayarat, dalam penelitian menggunakan uji normalitas dan uji linieritas. Kedua yaitu dengan uji korelasi.

\footnotetext{
${ }^{7}$ Sukayati, \& Wulandari, S. Pembelajaran Tematik di SD. (Yogyakarta: PPPTK Matematika.2009),hal, 23
} 


\section{HASIL PENELITIAN DAN PEMBAHASAN}

\section{Media Audio Visual $(X)$}

Mengukur variabel media audio visual yaitu dengan menggunakan lembar angket yang terdiri dari 20 butir dalam bentuk angket tertutup dan dengan menggunakan skala likert. Dari 31 responden yang telah dilakukan pengujian diperoleh data dengan skor terbesar yaitu 83 dan dengan skor terkecil yaitu 60 dengan mean 72,0968, median 71, mode 68 dan standar deviasi sebesar 6,16633. Nilai N sebanyak 31 peserta didik sehingga diperoleh kelas interval berjumlah 6 kelas dan panjang kelas yang berjumlah 4 .

Histogram skor variabel media audio visual kelas IV SD Negeri Belahantengah Mojokerto dapat dilihat pada Gambar 1.

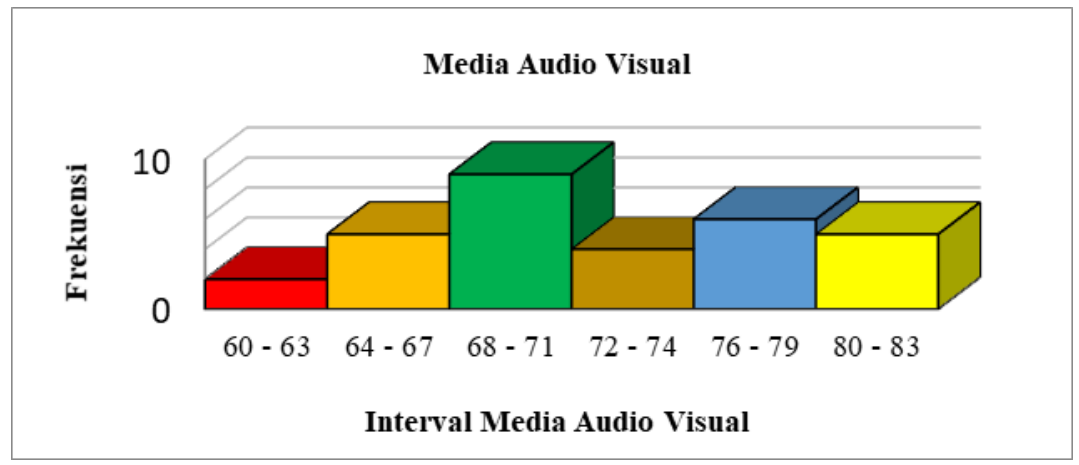

\section{Gambar 1. Histogram Media Audio Visual}

Jika skor responden dikelompokkan ke dalam distribusi kategori, diperoleh 26 peserta didik $(38,710 \%)$ berada dalam kelompok tertinggi, 19 peserta didik $(61,290 \%)$ ke dalam kelompok sedang, dan 0 peserta didik (0\%) berada dalam kelompok rendah. Data ini mengindikasikan bahwa 61,290\% responden yang menjadi subjek penelitian ini memberikan respon penerapan media audio visual dalam pembelajaran kelas IV tema 3 subtema 1 pembelajaran 1 tergolong sedang.

Hasil distribusi kategori media audio visual dapat digambarkan dalam diagram pie seperti pada Gambar 2. 


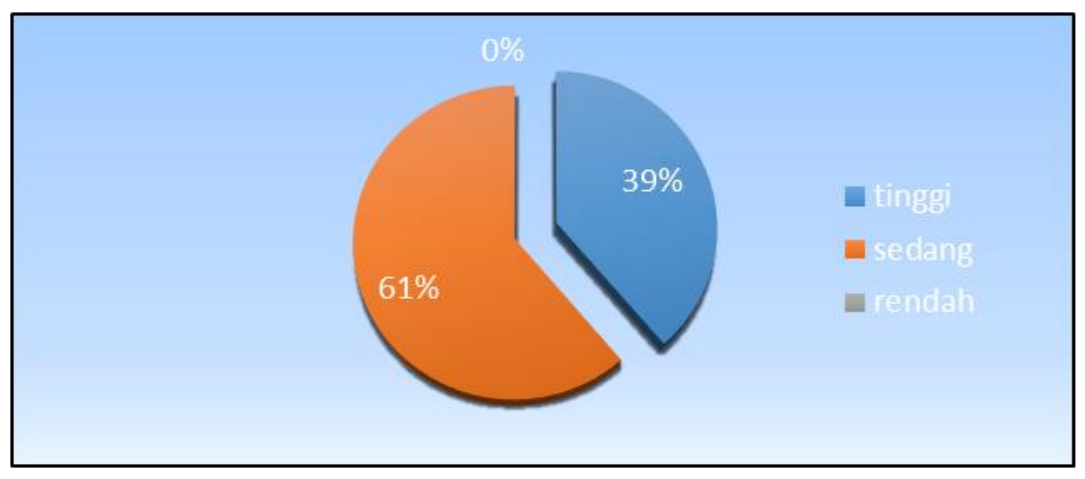

Gambar 2. Diagram Pie Media Audio Visual

\section{Hasil Belajar $(Y)$}

Mengukur variabel hasil belajar peserta didik kelas IV SD Negeri Belahantengah Mojokerto pada tema 3 subtema 1 pembelajaran 1 diperoleh dengan memakai lembur tes yang mencakup 15 soal multiple choice dan 5 soal isian singkat. Dari 31 responden yang telah dilakukan pengujian diperoleh sebesar 96 sebagai skor terbesar dan sebesar 52 sebagai skor terkecil. Dengan mean 77,8065, median 76, mode 76, dan standar deviasi sebesar 11,4467. Nilai N sebanyak 31 peserta didik sehingga didapatkan kelas interval berjumlah 6 kelas dan panjang kelas dengan total 8 .

Histogram skor variabel hasil belajar bisa diamati pada Gambar 3.

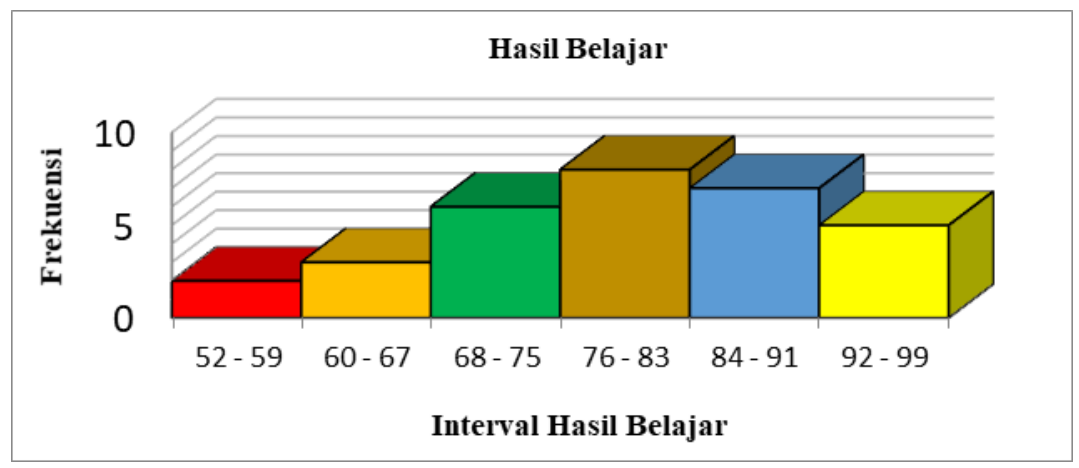

Gambar 3. Histogram Hasil Belajar

Jika skor responden dikelompokkan ke dalam distribusi kategori, diperoleh 3 peserta didik $(9,677 \%)$ berada dalam kelompok tinggi, 26 peserta didik $(83,871 \%)$ berada dalam kelompok sedang, dan 2 peserta didik $(6,452 \%)$ berada dalam kelompok rendah. 
Hasil distribusi kategori tes hasil belajar digambarkan dalam diagram pie, seperti pada Gambar 4.

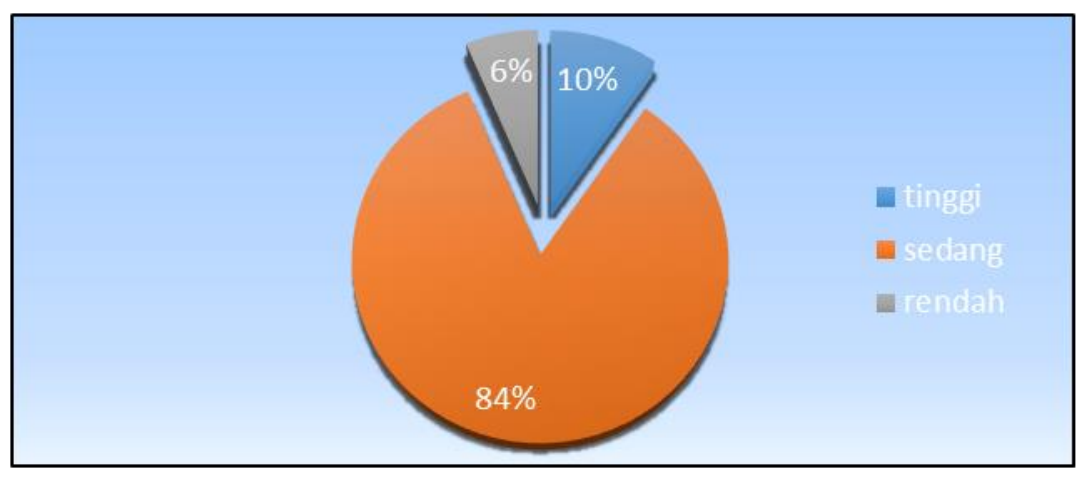

Gambar 4. Diagram Pie Hasil Belajar

\section{Uji Prasyarat}

\section{(1)Uji Normalitas}

Uji normalitas merupakan pengecekan data hasil penelitan dengan tujuan untuk melihat ikatan variabel $X$ dan variabel $Y$ apakah sudah berdistribusi normal atau belum.

Uji normalitas dengan rumus Shapiro-Wilk digunakan dalam pengujian data penelitian ini. Standar atau tolak ukur pengukuran yaitu data dinyatakan berdistribusi normal, jika nilai Sig > 5\%. Sebaliknya data dinyatakan tidak berdistribusi normal, jika nilai signifikasi $<5 \%$.

Pengujian normalitas pada penelitian ini memakai bantuan SPSS. Untuk variabel $X$ diperoleh Sig $=0,555$ untuk $\alpha=0,05$, hal ini menyatakan bahwa Sig $>\alpha$. Yang artinya data skor media audio visual berdistribusi normal. Kemudian untuk hasil analisis data hasil belajar didapatkan 0,462 >0,555 hal ini menunjukkan nilai Sig $>\alpha$, yang artinya variabel $Y$ berdistribusi normal. Kesimpulan dari penjelasan kedua kelompok data/variabel tersebut (Variabel $X$ dan $Y$ ) yaitu berdistribusi normal.

\section{(2)Uji Linieritas}

Pengujian ini dipakai untuk memverifikasi apakah terdapat ikatan yang linier antara variabel $X$ dan variabel $Y$. Standar atau tolak ukur yang dipakai yakni nilai Sig $>\alpha=0,05$, maka kedua variabel dinyatakan mempunai ikatan yang linier. 
Berdasarkan pengujian yang dilakukan dengan bantuan SPSS didapatkan hasil output dengan bantuan tabel ANOVA. Diperoleh nilai signifikasi 0,768> $\alpha=0,05$. Dapat diambil kesimpulan variabel $X$ dan $Y$ memiliki ikatan yang linier.

\section{Uji Korelasi}

Pengujian ini dilakukan guna mengetaui adanya ikatan antara variabel $X$ dengan $Y$. Pada penelitian ini yakni adanya hubungan antara media audio visual dengan hasil belajar yang dilakukan pada kelas IV di SD Negeri Belahantengah Mojokerto.

Uji korelasi dilakukan berdasarkan tolak ukur yakni Ha (Hipotesis alternatif) diterima, jika hasil $\mathrm{r}_{\text {hitung }}$ lebih besar dari $\mathrm{r}_{\text {tabel }}$, dengan signifikasi ( $\alpha$ ) 0,05. Sebaliknya Ho (Hipotesis nihil) dinyatakan ditolak, apabila $\mathrm{r}_{\text {hitung }}$ lebih kecil $\mathbf{r}_{\text {tabel }}$ dengan signifikasi $(\alpha) 0,05$.

Berdasakan pengujian dan dilakukan penghitungan, diperoleh $\mathrm{r}_{\text {hitung }}$ sebesar 0,813 dengan taraf $\operatorname{Sig}=0,05$, dan nilai $\mathrm{N}=31$, didapatkan $\mathrm{r}_{\text {tebel }}=0,355$. Data tersebut menunjukkan jumlah $\mathrm{r}_{\text {hitung }}>\mathrm{r}_{\text {tabel }}$ sehingga dapat ditarik kesimpulan variabel $X$ dan $Y$ memiliki korelasi/hubungan dengan interpretasi tingkat hubngan tinggi. Yang artinya yakni terdapat korelasi antara media audio visual dengan hasil belajar.

\section{PEMBAHASAN}

Tujuan dilaksanakannya penelitian ini yakni untuk menyelidiki adanya korelasi antara media audio visual dnegan hasil belajar kelas IV tema 3 subtema 1 pembelajaran 1 di SD Negeri Belahantengah Mojokerto tahun ajaran 2019/2020.

Lembar angket dan lembar tes merupakan instrumen yang dipakai dalam penelitian saat ini. Lembar angket digunakan mengambil data tentang respon hasil pengaplikasian media audio visual dalam proses pembelajaran. Sedangkan lembar tes diberikan dalam bentuk evaluasi ulangan harian yang digunakan dalam pengambilan data hasil belajar. Berdasarkan hasil uji korelasi data media audio visual dengan hasil belajar keles IV temas 3 subtama 1 pembeljran 1 menunjukkan nilai $\mathrm{r}_{\text {hitung }}=0,813$ dan $\mathrm{r}_{\text {tabel }}=0,3555$ dengan nilai signifikasi 
( $\alpha$ ) 0,05. Berdasarkan data tersebut, nilai $r_{h i t u n g}>r_{\text {tabel }}$, sehingga dapat ditarik kesimpulan $\mathrm{Ha}$ (Hipotesis alternatif) diterima yang bearti terdapat korelasi antara media audio visual dnegan hasil belajar kelas IV tema 3 subteme 1 pembelajaran 1 di SD Negeri Belahan tengah Mojokerto dengan interprestasi tingkat hubungan tinggi.

Pengunaan media audio belajar dalam proses belajar memiliki beberapa kelebihan,yaitu: (1) pembelajaran yang diperoleh peserta lebih efektif, karena baik dengan gaya bahasa audio maupun visual dalam terlayani dengan baik; (2) pengalaman belajar jauh lebih jelas atau nyata; (3) peserta didik lebih gampang memahami materi, dikarenakan materi yang diperoleh peserta didik secara langsung bukan sekedar berangan-angan; (4) peserta didik lebih tertarik dan lebih senang jika pembelajaran memakai atau dengan mengaplikasikan media audio visual. Sedangkan kekurangannya dijelaskan berikut ini: (1) waktu pembuatan media yang relatif lama; (2) dalam pembuatannya dibutuhkan kreatifitas dan ketelitian; (3) mahalnya biaya pembuatan media; (4) apabila peralatan yang dibutuhkan tidak ada, maka akan mengalami kesulitan dalam pembuatan medianya. $^{8}$

Kegiatan pembelajaran yang dilakukan dengan bantuan media audio visual memiliki kelebihan dibandingkan dengan pembelajaran tanpa bantuan media. Salah satu contohnya yaitu lebih berkonsentrasi serta peserta didik menjadi lebih terdorong dan terpikat pada materi yang diajarkan. Selain itu juga peserta didik menjadi lebih semangat dan tidak mudah bosan.

Penelitian ini secara empiris memiliki hubungan dengan penelitian terdahulu yang dilakukan oleh Tanty Albaniah, yang berasal dari Universitas Jambi. Peneliti ini meneliti Hubungan Pengguanaan Media Video Pelajaran Matematika Kelas IV SDN 76/1 Sungai Buluh. Hasil analisis penelitian tersebut diperoleh $\mathrm{r}_{\mathrm{xy}}=0,1025$ kemudian diperoleh $\mathrm{t}_{\text {hitung }} 0,37145$ dengan $\mathrm{t}_{\text {tabel }}=$ 1.7163.701. dari penelitian tersebut diambil kesimpulan yakni penggunaan media video dengan hasil belajar matematika terdapat hubungan yang saling terkait.

\footnotetext{
${ }^{8}$ Suryani, N., \& Dkk. Media Pembelajaran Inovatif dan Pengembangannya. (Bandung: Rosda Karya.2018),HAL,51
} 
Penelitian lainnya yaitu dilakukan oleh (Afridayanti, 2017), yang berasal dari Universitas Negeri Medan. Afridayanti melakukan penelitian Hubungan Pemanfaatan Media Audio Visual dengan Hasil Belajar IPS Siswa Kelas V SD Swasta Panca Budi Medan Tahun Ajaran 2016/2017. Hasil analisis penelitian tersebut diperoleh $t_{\text {hitung }}>\mathrm{t}_{\text {tabel }}$ yaitu $2,30>2,00$. Hal tersebut dapat ditarik kesimpulan penggunaan media audio visual yang baik maka akan berpengaruh baik pula pada hasil belajar IPS peserta didik.

Kesimpulan yang dapat diambil berdasarlan uraian yang sudah dijelaskan diatas, yaitu variabel $X$ (media audio visual) dengan variabel $Y$ (hasil belajar) memiliki korelasi yang kuat. Dibuktikan dengan hasil belajar yang diperoleh peserta didik menjadi lebih baik, hal tersebut karena peserta didik lebih mudah memahami materi yang disampaikan ketika proses belajar berlangsung.

\section{KESIMPULAN}

Kesimpulan yang didapat dari penelitian yang dilakukan di SD Negeri Belahantengah Mojokerto yaitu ada korelasi antara media audio visual dengan hasil belajar kelas IV tema 3 subtema 1 pembelajaran 1. Oleh karena itu disarankan kepada peserta didik apabila mengalami kondisi maupun situasi yang kurang efektif dalam suatu proses pembelajaran, diharapkan dapat mengkomunikasikan kepada pihak - pihak sekolah baik guru maupun kepala sekolah. Disarankan juga kepada pendidik, diharapkan dalam setiap kegiatan menggajar selalu menggunakan bantuan media pembelajaran dalam menyampaikan materinya, baik berupa media audio visual maupun media pembelajaran lainnya, sehingga peserta didik jadi lebih mudah mencerna dan semakin tertarik dengan materi yang diajarkan. Dan kepada pihak sekolah, sebaiknya memfasilitasi baik sarana maupun prasarana yang diperlukan guru sebagai pendidik sehingga dapat mempermudah dalam proses belajar mengajar. 


\section{DAFTAR PUSTAKA}

Afridayanti. (2017). Hubungan Pemanfaatan Media Audio Visual dengan Hasil Belajar IPS Siswa Kelas V SD Swasta Panca Budi Medan Tahun Ajaran 2016/2017. Universitas Negeri Medan.

Arsyad, A. (2013). Media Pembelajaran. Jakarta: Pustaka Belajar.

Dimyanti \& Mudjiono. (2013). Belajar\&Pembelajaran. In belajar\&pembelajaran.

Fanani, A., \& Kusmaharti, D. (2018). Pengembangan Perangkat Pembelajaran Sekolah Dasar. Surabaya: Adi Buana University Press.

Leksono, I. P., \& Yustitia, V. (2016). Belajar dan Pembelajaran. Surabaya: Adi Buana University Press.

Purwanto. (2013). Evaluasi Hasil Belajar. Yogyakarta: Pustaka Belajar.

Sukayati, \& Wulandari, S. (2009). Pembelajaran Tematik di SD. Yogyakarta: PPPTK Matematika.

Suryani, N., \& Dkk. (2018). Media Pembelajaran Inovatif dan Pengembangannya. Bandung: Rosda Karya. 